\title{
Variations in Mid-Continent Rift magma volumes consistent with microplate evolution
}

\author{
Miguel Merino, ${ }^{1}$ G. Randy Keller, ${ }^{2}$ Seth Stein, ${ }^{1}$ and Carol Stein ${ }^{3}$ \\ Received 19 December 2012; revised 21 February 2013; accepted 23 February 2013; published 28 April 2013.
}

[1] Modeling of gravity data along the $\sim 1.1$ Ga failed MidContinent Rift System shows systematic patterns in magma volume between and along the rift's two arms. The volume of magma increases towards the Lake Superior region, consistent with magma flowing away from a hotspot source there. The west arm experienced significantly more magmatism. These patterns are consistent with a model in which the two rift arms acted as boundaries of a microplate. The volume of magma along the west arm increases with distance from the Euler pole, indicating that it acted essentially as a spreading ridge, whereas the much smaller magma volumes along the east arm are consistent with its acting as a leaky transform. This view of the rift system's evolution is compatible with the rift being part of an evolving plate boundary system rather than an isolated episode of midplate volcanism. Citation: Merino, M., G. R. Keller, S. Stein, and C. Stein (2013), Variations in Mid-Continent Rift magma volumes consistent with microplate evolution, Geophys. Res. Lett., 40, 1513-1516, doi:10.1002/grl.50295.

\section{Introduction}

[2] The Mid-Continent Rift System (MCRS) is one of the most prominent features on the Bouguer gravity map of the central United States (Figure 1). The rift formed at $\sim 1.1 \mathrm{Ga}$, recorded by two pulses of magmatic activity lasting $\sim 15 \mathrm{Myr}$ [White, 1997], making it one of the most extensive paleorifts in the world [Hinze et al., 1997]. Petrologic and geochemical models favor the MCRS having been formed in the continental interior by a mantle plume [Davis and Green, 1997; Nicholson et al., 1997; Vervoort et al., 2007]. Alternatively, many tectonic models view the rift as having formed as a part of the Grenville orogeny [McWilliams and Dunlop, 1978; Gordon and Hempton, 1986], which is the series of 1.3-0.9 Ga tectonic events associated with the assembly of Rodinia [Whitmeyer and Karlstrom, 2007]. In such interpretations, northwest-directed convergence at the southern margin of Laurentia (Proterozoic North America) caused extension and magmatism to the northwest, including

All Supporting Information may be found in the online version of this article.

${ }^{1}$ Department of Earth and Planetary Sciences, Northwestern University, Evanston, Illinois, USA.

${ }^{2}$ ConocoPhillips School of Geology and Geophysics, University of Oklahoma, Norman, Oklahoma, USA.

${ }^{3}$ Department of Earth and Environmental Sciences, University of Illinois at Chicago, Chicago, Illinois, USA.

Corresponding author: M. Merino, Department of Earth and Planetary Sciences, Northwestern University, Evanston, IL 60208, USA. (miguel@earth.northwestern.edu)

(C)2013. American Geophysical Union. All Rights Reserved. 0094-8276/13/10.1002/grl.50295 formation of the MCRS. Volcanic activity was followed by deposition of clastic sediments in subsiding basins and subsequent faulting of these lithified sediments [Halls, 1982; Wold and Hinze, 1982]. Eventually, changing far-field stresses, as the Grenville orogeny progressed, are thought to have caused compression that slowed and stopped the extension, leaving a failed rift [Cannon, 1994].

[3] The $2000 \mathrm{~km}$ long MCRS, which is comparable in length to the presently active East African and Baikal rifts, has two major arms meeting in the Lake Superior region. One extends southwestward at least as far as Kansas, and the other extends southeastward at least through Michigan. Because the rift is hidden beneath Phanerozoic sedimentary rocks except where it is exposed in the Lake Superior region, its location and geological characteristics are primarily inferred from the gravity and magnetic anomalies, extrapolations from the outcrop area, seismic reflection profiles, and a few basement drill holes.

[4] Early seismic studies indicate that the crust beneath Lake Superior and portions of the west rift arm is thickened and anomalously dense [Ocola and Meyer, 1973]. Similar crustal thickening was found in the east arm by Halls [1982]. Seismic reflection data from the GLIMPCE program of active source studies across Lake Superior [Cannon et al., 1989; Shay and Trehu, 1993] show that the crust was initially thinned to about one fourth of its original thickness. The resulting basin was filled with extrusive volcanics and sediments, and volcanic underplating, producing a rift pillow, subsequently thickened the lower crust. Such crustal rethickening has been identified in other rifts [Thybo and Nielsen, 2009]. Soon after magma had stopped erupting, the normal faults were inverted to reverse motion, presumably due to the Grenville orogeny [Cannon, 1994].

[5] The highly magnetic and dense mafic igneous rocks filling the rift basin were juxtaposed by high-angle reverse faulting against the less magnetic and less dense clastic rocks deposited in the basins that originally overlaid them [King and Zietz, 1971]. The resulting gravity and magnetic anomalies have been used to map the west arm of the rift, which extends into southern Kansas and perhaps to southern Oklahoma [Adams and Keller, 1996]. Gravity and magnetic anomalies also show that the rift continues into the basement beneath the Michigan basin [Oray et al., 1973]. This interpretation has been confirmed by drilling in the Michigan basin that encountered a thick section of clastic sedimentary rocks underlain by mafic volcanic rocks [Sleep and Sloss, 1978] and reflection seismic studies [Brown et al., 1982] that detected the graben structure sampled by the deep drill hole. The southern limit of the east arm is generally placed in southeast Michigan, but a series of $\mathrm{N}-\mathrm{S}$ trending gravity maxima that extend into Ohio, Kentucky, and Tennessee may be continuations of this arm [Halls, 1978; Keller 

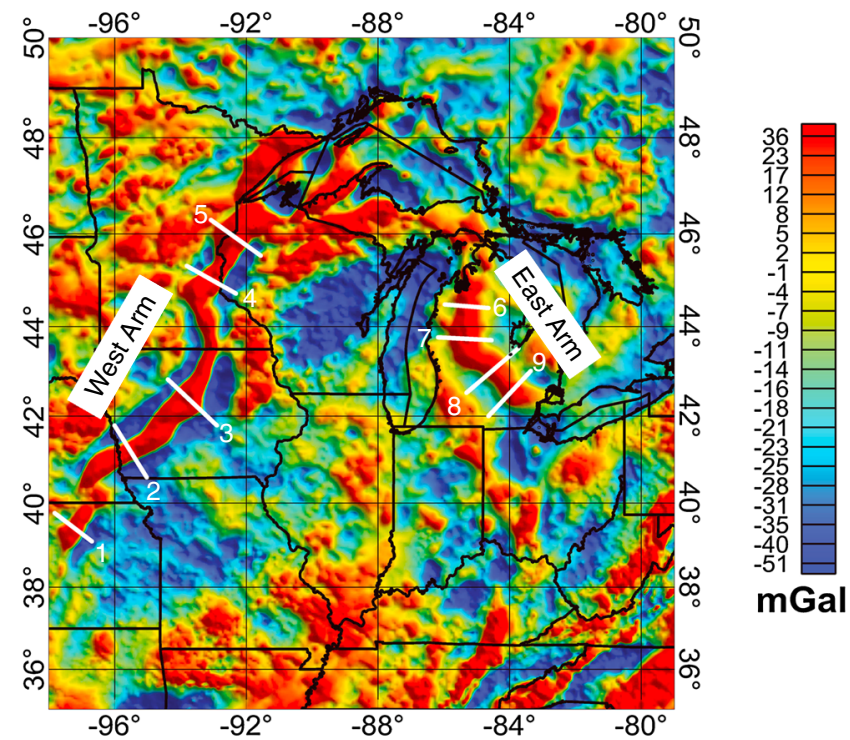

Figure 1. Bouguer anomaly gravity map of the central United States. White lines represent gravity profile and model locations, which are numbered and cross the anomalies that delineate the rift system. Lines $1,2,5,8$, and 9 are located near seismic lines.

et al., 1982]. Lidiak and Zietz [1976] also suggested the presence of related rifts in the eastern Kentucky area.

\section{Gravity Analysis}

[6] We examine variations in the volume of magmatic rocks along the east and west arms to seek additional insight
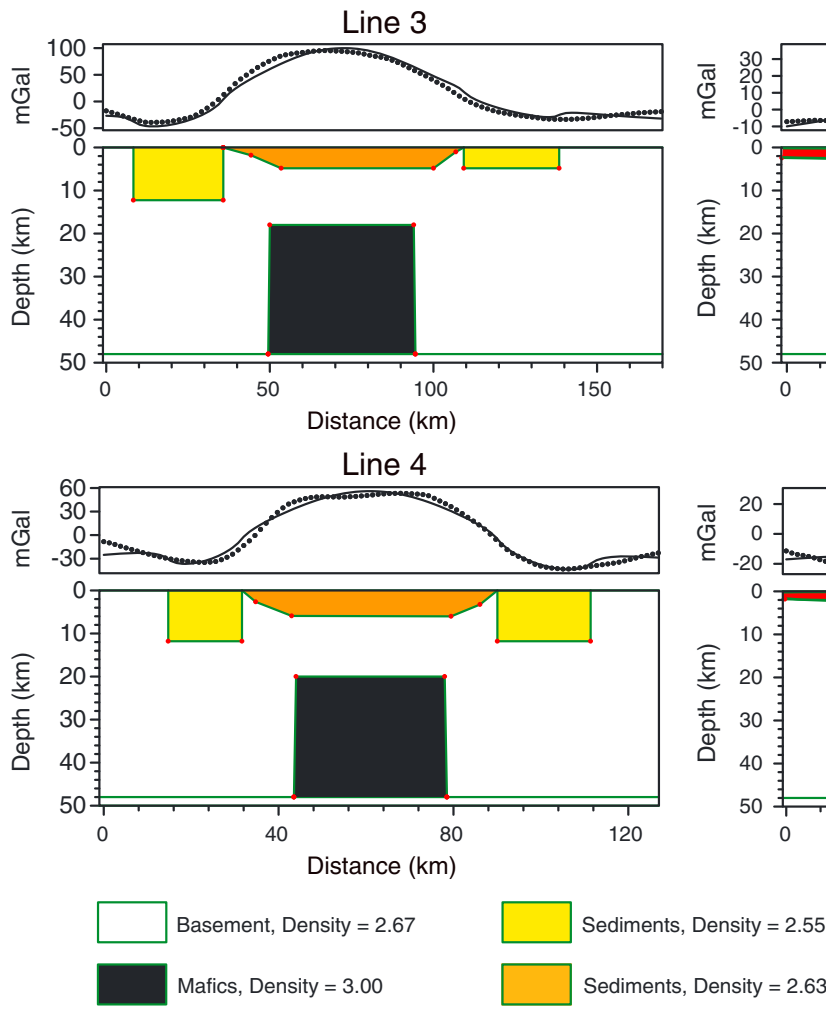

into the rift system's evolution. Numerous 2-D gravity and magnetic models along parts of the MCRS have been developed [Hinze et al., 1982; Wold and Hinze, 1982; Van Schmus and Hinze, 1985; Cannon et al., 1989; Woelk and Hinze, 1991; Hinze et al., 1992; Thomas and Teskey, 1994]. However, these models were constructed using a variety of software and modeling schemes, making it difficult to compare results from different profiles. Hence, we conducted consistent modeling across both arms of the rift, allowing direct comparisons.

[7] The gravity data (Figure 1) were compiled from the PACES database for land areas [Keller et al., 2002, 2006; Hinze et al., 2005] and TOPEX satellite data for the Great Lakes [Sandwell and Smith, 2009]. Only the Bouguer anomaly land data were used to create gravity models.

[8] Gravity profile locations were selected to give good spatial coverage of the rift arms and, when possible, correlate with previous seismic reflection and gravity profiles. However, the seismic data have poor resolution in the lower crust; hence, they do not significantly impact our gravity models. Although the Lake Superior region of the MCRS has a significant amount of seismic data, it was not modeled because the gravity data do not show a simple trend along the rift. This choice also avoided the need to merge the higher quality land data with TOPEX satellite data.

[9] We used a generalized model inspired by a COCORP seismic reflection line in Kansas [Serpa et al., 1984], as reinterpreted by Woelk and Hinze [1991]. This model has mafic intrusions, a sedimentary basin overlying a large basaltic body, and large flanking sedimentary basins. Thomas and Teskey [1994] infer that sediment densities in the northern MCRS range from 2.25 to $2.66 \mathrm{~g} / \mathrm{cm}^{3}$ depending
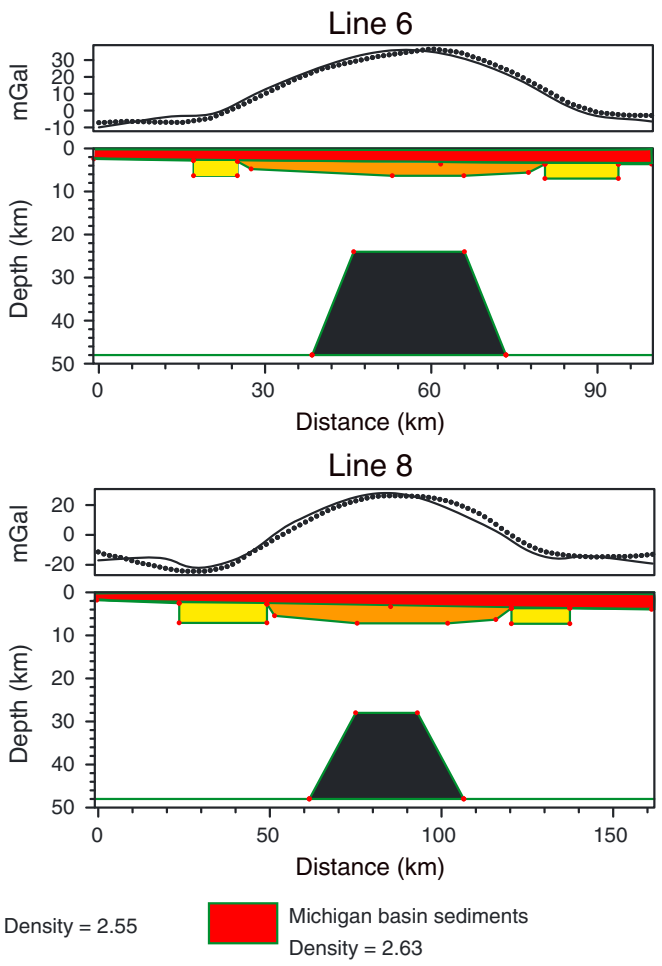

Figure 2. Four representative gravity models of the nine computed, two each from the east and west arms. The other profiles are shown in supplemental Figure 1. Black dots are observed gravity; black line is calculated gravity. 

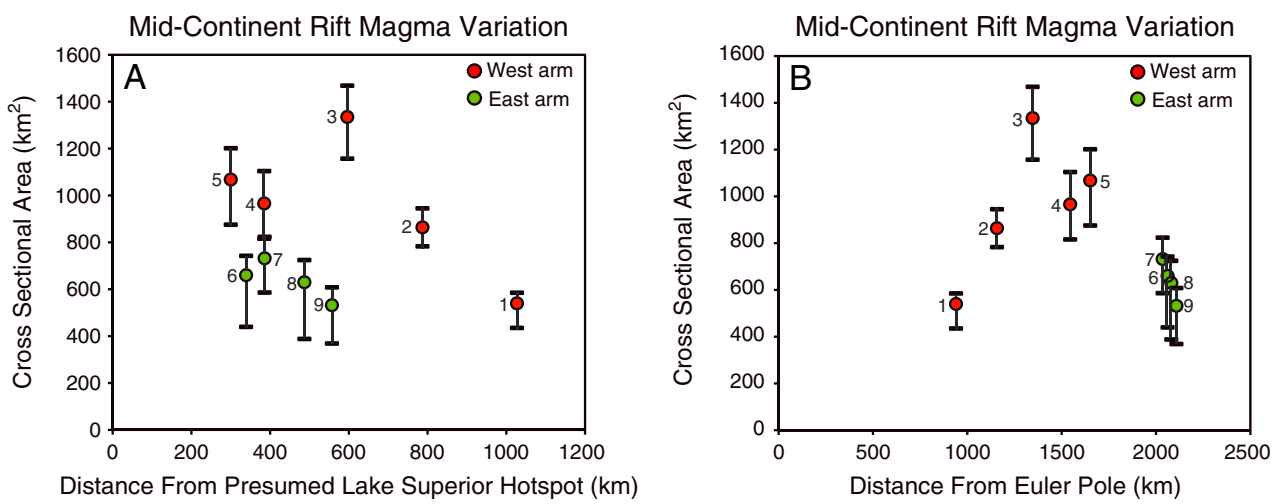

Figure 3. (a) Cross-sectional magma areas in the models plotted as a function of distance from the Lake Superior region. The areas increase toward the Lake Superior region and the west arm has significantly more magma than the east arm. (b) Cross-sectional magma areas in the models plotted against distance from the Chase and Gilmer [1973] Euler pole. Black bars show the range in cross-sectional areas for the other four modeling schemes.

on the geologic unit. We use densities of $2.63 \mathrm{~g} / \mathrm{cm}^{3}$ in the central basin and $2.55 \mathrm{~g} / \mathrm{cm}^{3}$ in the flanking basins.

[10] For simplicity, we treat the mafic intrusions as single magmatic bodies represented by equilateral trapezoids with a density of $3.00 \mathrm{~g} / \mathrm{cm}^{3}$ underlain by a Moho extracted from CRUST2.0 [Bassin et al., 2000]. A best fitting model for each profile was found by a grid search. We also ran our original models with mafic densities of 2.94 and $3.06 \mathrm{~g} /$ $\mathrm{cm}^{3}$. Two additional modeling schemes are available in the supplemental information: one uses the Moho from NA07 [Bedle and van der Lee, 2009], and the second includes a shallow basalt slab beneath the central basin. The volumetric trends are similar for all model sets.

\section{Results and Interpretation}

[11] The models give insight into differences between the arms of the MCRS. The Michigan basin overlies the east arm, and the west arm has a higher central gravity anomaly with large flanking negative anomalies. Figure 2 shows how these differences manifest in the gravity models. Because the Michigan basin is not centered on the rift, its sediments appear as a gently dipping layer over the entire area that has little effect on the gravity models. The west arm's more intense central anomalies are modeled by larger rift magmatic intrusions. The negative anomalies on this arm's flanks are modeled as large sediment-filled flanking basins, which are deeper than the central basin. This geometry reflects the tectonic inversion that raised the central portion of the rift. Similar flanking basins are also present in the east arm models, but are similar in depth to the central sediment basin.

[12] By integrating the cross-sectional areas of the intrusions along the rift (Figure 3), we estimate the total magma volume, excluding the Lake Superior region, is between $8.69 \times 10^{5}$ and $1.2 \times 10^{6} \mathrm{~km}^{3}$. Scaling up the volume to the total length of the rift gives a range of $1.34 \times 10^{6}$ to $1.85 \times 10^{6} \mathrm{~km}^{3}$ for the entire MCRS. This is in good agreement with previous estimates for the entire MCRS of $1.3 \times 10^{6} \mathrm{~km}^{3}$ [Hutchinson et al., 1990].

[13] Examination of the variation in cross-sectional areas along the rift shows clear trends. First, the volume of magma increases towards the Lake Superior region (Figure 3), where thick basalt assemblages are known to exist. This trend is consistent with magma flowing away from a source in the Lake Superior region. Second, the west arm has significantly more magma. This difference is not an obvious consequence of flow from a northern source, although it not precluded by such a model.

[14] However, the magma volumes are consistent with a model (Figure 4) in which the two rift arms acted as boundaries of a microplate. Chase and Gilmer [1973] found an Euler pole for such a model by treating offsets in the gravity maxima as transform faults, and using the width of the central gravity anomaly as a measure of total spreading. As shown, the volume of magma we infer along the west arm increases with distance from the Euler pole. Thus, the results of analyzing more recent gravity data are also consistent with the microplate model. Moreover, the much smaller volumes of magma along the east arm are consistent with this arm being a leaky transform, along which transtensional motion permits some magmatism.

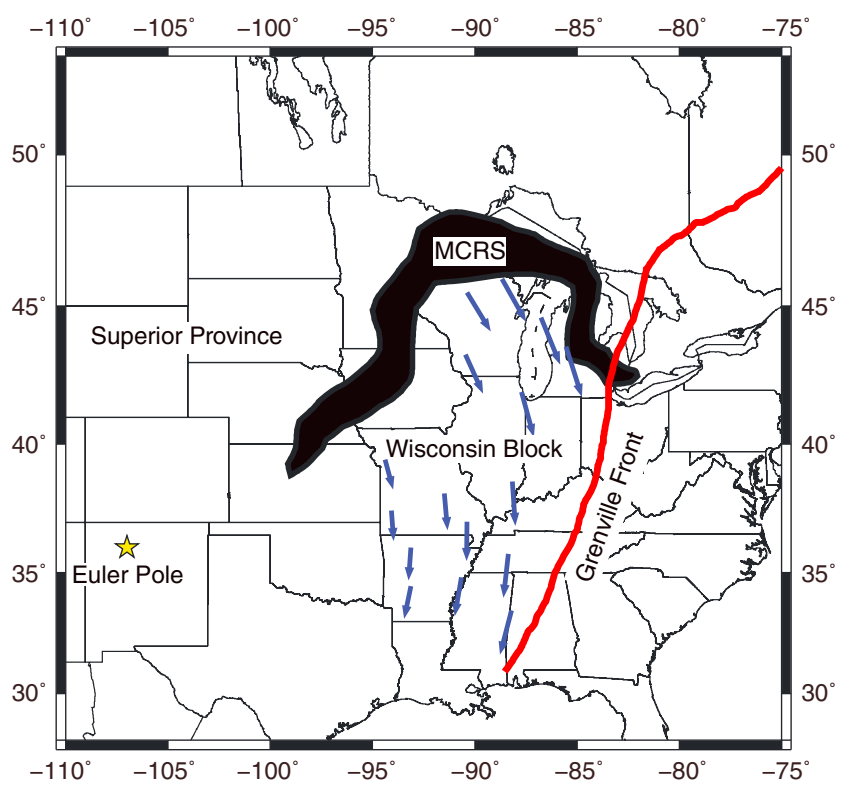

Figure 4. Schematic microplate model with the Wisconsin Block rotating away from the Superior Province. This microplate model is consistent with the magma variations shown in Figure 3b. 


\section{MERINO ET AL.: VARIATIONS IN MID-CONTINENT RIFT MAGMA}

[15] Viewing the MCRS's evolution as showing rotation of a rigid microplate does not preclude its having been started by a mantle plume. However, this view is consistent with the rift having been part of an evolving regional plate boundary system [Whitmeyer and Karlstrom, 2007] rather than an isolated episode of midplate volcanism.

[16] Acknowledgments. We thank Fausto Ferraccioli and an anonymous reviewer for their comments, which lead to significant improvements in the manuscript. This work has been supported by NSF grant EAR-1148088.

\section{References}

Adams, D. C., and G. R. Keller (1996), Precambrian basement geology of the Permian Basin region of West Texas and eastern New Mexico: A geophysical perspective, AAPG Bull., 80(3), 410-431.

Bassin, C., G. Laske, and G. Masters (2000), The current limits of resolution for surface wave tomography in North America, Eos, Trans., Am. Geophys. Union, 81(48, Suppl.), 897.

Bedle, H., and S. van der Lee (2009), S velocity variations beneath North America, J. Geophys. Res., 114, B07308.

Brown, L., L. Jensen, J. Oliver, S. Kaufman, and D. Steiner (1982), Rift structure beneath the Michigan Basin from COCORP profiling, Geology, 10(12), 645-649.

Cannon, W. F. (1994), Closing of the Midcontinent Rift - A far-field effect of Grenvillian compression, Geology, 22(2), 155-158.

Cannon, W. F., et al. (1989), The North-American Midcontinent Rift beneath Lake Superior from GLIMPCE seismic reflection profiling, Tectonics, 8(2), 305-332.

Chase, C. G., and T. H. Gilmer (1973), Precambrian plate tectonics Midcontinent gravity high, Earth Planet. Sci. Lett., 21(1), 70-78.

Davis, D. W., and J. C. Green (1997), Geochronology of the North American Midcontinent rift in western Lake Superior and implications for its geodynamic evolution, Can. J. Earth Sci., 34(4), 476-488, doi:10.1139/ e17-039.

Gordon, M. B., and M. R. Hempton (1986), Collision-induced rifting: The Grenville Orogeny and the Keweenawan Rift of North America, Tectonophysics, 127(1-2), 1-25, doi:10.1016/0040-1951(86)90076-4.

Halls, H. (1978), The late Precambrian central North America rift systemA survey of recent geological and geophysical investigations, in Tectonics and Geophysics of Continental Rifts: NATO Advanced Study Institute, Series C, Mathematical and Physical Sciences, edited by E. R. Neumann, and I. Ramberg, pp. 111-123, Reidel, Dordrecht, NL.

Halls, H. C. (1982), Crustal thickness in the Lake Superior region, in Geology and Tectonics of the Lake Superior Basin, Geological Society of America Memoir, edited by R. J. Wold and W. J. Hinze, pp. 239-243, Geological Society of America, Boulder, CO

Hinze, W. J., R. J. Wold, and N. W. O'Hara (1982), Gravity and magnetic anomaly studies of Lake Superior, in Geology and Tectonics of the Lake Superior Basin, Geological Society of America Memoir, edited by R. J. Wold, and W. J. Hinze, pp. 203-221, Geological Society of America, Boulder, CO.

Hinze, W. J., D. J. Allen, A. J. Fox, D. Sunwood, T. Woelk, and A. G. Green (1992), Geophysical investigations and crustal structure of the North American Midcontinent Rift system, Tectonophysics, 213(1-2), 17-32, doi:10.1016/0040-1951(92)90248-5.

Hinze, W. J., D. J. Allen, L. W. Braile, and J. Mariano (1997), The Midcontinent Rift System; A major Proterozoic continental rift, in Middle Proterozoic to Cambrian rifting, central North America, edited by R. W. Ojakangas, A. B. Dickas, B. Albert, and J. C. Green, pp. 7-35, Geological Society of America, Boulder, CO

Hinze, W. J., C. Aiken, J. Brozena, B. Coakley, D. Dater, G. Flanagan, R. Forsberg, T. Hildenbrand, G. R. Keller, and J. Kellogg (2005), New standards for reducing gravity data: The North American gravity database, Geophysics, 70(4), J25-J32.
Hutchinson, D. R., R. S. White, W. F. Cannon, and K. J. Schulz (1990), Keweenaw hot spot: geophysical evidence for a $1.1 \mathrm{Ga}$ mantle plume beneath the Midcontinent Rift system, J. Geophys. Res., 95(B7), 10869-10884, doi:10.1029/JB095iB07p10869.

Keller, G., A. Bland, and J. Greenberg (1982), Evidence for a major Late Precambrian tectonic event (rifting?) in the eastern midcontinent region, United States, Tectonics, 1(2), 213-223, doi:10.1029/ TC001i002p00213.

Keller, G. R., T. G. Hildenbrand, R. Kucks, D. Roman, and A. M. Hittelman (2002), Upgraded gravity anomaly base of the United States, Leading Edge, 21(4), 366-367.

Keller, G. R., et al. (2006), A community effort to construct a gravity database for the United States and an associated web portal, in Geoinformatics: Data to Knowledge, edited by A. K. Sinha, pp. 21-34, Geological Society of America, Boulder, CO.

King, E. R., and I. Zietz (1971), Aeromagnetic study of the midcontinent gravity high of central United States, Geol. Soc. Am. Bull., 82(8), 2187-2208.

Lidiak, E. G., and I. Zietz (1976), Interpretation of aeromagnetic anomalies between latitudes 37 degrees $\mathrm{N}$ and 38 degrees $\mathrm{N}$ in the eastern and central United States, Geol. Soc. Am. Special Paper, 167, 37.

McWilliams, M., and D. Dunlop (1978), Grenville paleomagnetism and tectonics, Can. J. Earth Sci., 15(5), 687-695.

Nicholson, S. W., S. B. Shirey, K. J. Schulz, and J. C. Green (1997), Riftwide correlation of $1.1 \mathrm{Ga}$ midcontinent rift system basalts: Implications for multiple mantle sources during rift development, Can. J. Earth Sci., 34(4), 504-520.

Ocola, L. C., and R. P. Meyer (1973), Central North American rift system 1. Structure of the axial zone from seismic and gravimetric data, J. Geophys. Res., 78(23), 5173-5194.

Oray, E., W. J. Hinze, and N. O'Hara (1973), Gravity and magnetic evidence for the eastern termination of the Lake Superior syncline, Geol. Soc. Am. Bull., 84(8), 2763-2780.

Sandwell, D. T., and W. H. F. Smith (2009), Global marine gravity from retracked Geosat and ERS-1 altimetry: Ridge segmentation versus spreading rate, J. Geophys. Res., 114(B01411), B01411.

Serpa, L., T. Setzer, H. Farmer, L. Brown, J. Oliver, S. Kaufman, J. Sharp, and D. W. Steeples (1984), Structure of the southern Keweenawan rift from COCORP surveys across the Midcontinent geophysical anomaly in northeastern Kansas, Tectonics, 3(3), 367-384.

Shay, J., and A. Trehu (1993), Crustal structure of the central graben of the Midcontinent Rift beneath Lake Superior, Tectonophysics, 225(4), $301-335$.

Sleep, N. H., and L. Sloss (1978), A deep borehole in the Michigan basin, J. Geophys. Res., 83(B12), 5815-5819.

Thomas, M., and D. Teskey (1994), An interpretation of gravity anomalies over the Midcontinent Rift, Lake Superior, constrained by GLIMPCE seismic and aeromagnetic data, Can. J. Earth Sci., 31(4), 682-697.

Thybo, H., and C. A. Nielsen (2009), Magma-compensated crustal thinning in continental rift zones, Nature, 457(7231), 873-876, doi:10.1038/ nature07688.

Van Schmus, W. R., and W. J. Hinze (1985), The Midcontinent Rift System, Annu. Rev. Earth Planet. Sci., 13, 345-383.

Vervoort, J. D., K. Wirth, B. Kennedy, T. Sandland, and K. S. Hatpp (2007), The magmatic evolution of the Midcontinent rift: New geochronologic and geochemical evidence from felsic magmatism, Precambrian Res., 157(1-4), 235-268, doi:10.1016/j.precamres.2007.02.019.

White, R. S. (1997), Mantle temperature and lithospheric thinning beneath the Midcontinent rift system: Evidence from magmatism and subsidence, Can. J. Earth Sci., 34(4), 464-475.

Whitmeyer, S. J., and K. E. Karlstrom (2007), Tectonic model for the Proterozoic growth of North America, Geosphere, 3(4), 220-259, doi:10.1130/ges00055.1.

Woelk, T. S., and W. J. Hinze (1991), Model of the Midcontinent Rift system in northeastern Kansas, Geology, 19(3), 277-280.

Wold, R. J., and W. J. Hinze (1982), Geology and tectonics of the Lake Superior basin, Geol. Soc. Am. Mem., 156, 280. 